\title{
Village Development through Hydropower
}

\author{
Gyanendra Lal Pradhan
}

\begin{abstract}
This paper proposes a new model to develop small hydropower on the Public-Private Partnership (PPP) model, by developing one small hydro project in a district under the auspices of local institutions such as the District Development Committee (DDC), Village Development Committee (VDC), municipality, etc. , in partnership with an entrepreneur or the Federation of Nepalese Chambers of Commerce and Industries. This model will create wealth for the villages of the district; and local institutions need not look to the Nepal government for the development grant. Hydropower is the best means to bring in development that the local people aspire for. As hydro development requires infrastructure building of roads, transmission lines etc., it will open the door of opportunity in the district for rapid growth. At the beginning, 1-5 MW size is proposed and in later stages larger sizes can be attempted. As the entrepreneur puts in equity at the beginning, and only after project operation, shares are given to the locals. $A$ share structure of 70:30 is proposed for the entrepreneur and the local institutions respectively.
\end{abstract}

Key words: Public-Private Partnership, small hydropower, Nepal

\section{Introduction}

Tydropower potential rich Nepal has an annual 224 billion 1 cubic meter of surface run-off with over 20,000 litres of wateravailabletoaperson perday. Accordingtothestudymadeby Hydro Solutions, the total hydropower potential of Nepal stands at around 200,000 MW against the popularly assumed figure of 83,000 MW. From more than 6,000 rivers and rivulets of Nepal, around one million GW hours of electricity can be generated. This is equivalent to about 300 times of Nepal Electricity Authority's (NEA) present annual income of Rs.15 billion. But in spite of its immense hydropower potential, there is no water in household taps and the country is engulfed in darkness, reeling under 18 hours of load shedding in a day in dry season. About $60 \%$ of the Nepali population is still living in darkness.

Power cuts are severely impactingindustry, business and daily lives, debilitating the nation's productivity including in the rural economy. The national productivity loss due to load shedding is a whopping over 70 billion rupees per annum with industries being affected the most.

Remittance is one of the major contributors to Nepal's economy (contribution to the GDP is 17.4 percent). Remittance of over 200 billion rupees, which is almost equal to the nation's annual budget, is not beingused for development of infrastructure in the country. Rather, investments in real estate, consumable, etc., is an evolving whim in the market, not supporting national infrastructure development.

At a time when the country is suffering from power cuts and the concomitant economic downturn and the aspiration of the common people for development is on a continual rise, the districts of Nepal can be empowered to chart their development path by exploiting the hydro resources in their communities. Local communities have always depended on the central government to provide resources for their development. This dependency has retarded their growth and ability to take responsibility for their development as development packages and priorities vary with changes in the central government. To reduce such dependency it is proposed that each district should develop a 1 to $5 \mathrm{MW}$ hydropower plant on its own so that the plant will generate some resources that can be provided to the community to plan and implement local development activities acconding to their own priorities.

\section{Development Aspirations of the Local People}

Local people and communities seek roads, electricity, communication, health centers, local employment, education and market facilities. All these aspects of development are possible through the implementation of a hydropower project in a community. Hydropower requires infrastructure, labor and services for building the infrastructure and the project itself. Therefore, hydropower is the best means to bring in development that the local people aspire for.

\section{Technical Capability}

Developing hydropower requires financial, technical and managerial capability. A small hydropower plant can be built with fairly simple technology. As there are already many projects of this category developed or being developed in Nepal, there is sufficient Nepalese experience available. Therefore, there exists local capability in the private as well as public sector to design, build and operate power plants of this scale.

The 10-Year Hydropower Development Task Force has envisaged people's hydropower development in three phases over 10 years total of each $100 \mathrm{MW}$, contributing to $300 \mathrm{MW}$. This ownership model finds its place in the taskforce's report.

\section{Ownership Model}

The objective is to grant ownership of local hydro resources to local institutions and to empower them to chart their own development path jointly with entrepreneurs, to plan, lead, construct and operate the project. The ownership model must be such that the local DDCs and VDCs have a significant stake and authority over these resources. There may be districts that do not have the natural resource to develop small hydropower projects within their own territory. These districts could team up with their neighboring districts and share the investment and resources. If a district does not have the financial resources to develop and operate hydropower projects, it can invite other partners to fill the financial gap. These could be public partners like the Nepal 
ElectricityAuthority, orgroupslikelocal chapters of theFederation of Nepalese Chambers of Commerce and Industries (FNCCI) or any other Nepali private sector investor. Provision also must be made to involve all local individuals and other communities in the district. That will not only help to collect scattered resources but also to make the development project all inclusive. Technical support can berendered by Hydro Solutions. The government can invest in creation of infrastructure such as roads and transmission lines required for the project to make the project cheap.

In financing, entrepreneurs' support is pivotal. Seventy-five percent of the loan from the bank that comes as project finance is collateral-oriented as Nepali banks and financial institutions are risk averse by nature and are yet to learn the tricks of the risk assessment and risk management. Without credible and trusted entrepreneurs with collateral and adequate risk sharing arrangements, the bank does not issue loans.

\section{Financing Scheme}

Here is an example of a financing scheme proposed for these projects:

Project size: 5MW

Construction period: 2-3years

Project cost (@Rs. 150,000,000 per MW): Rs. 750,000,000

Equity required (@ 25\% of total cost): Rs. 187,500,000

DDC (local) ownership: 30\%

Entrepreneurs: $70 \%$ of total equity

The shares distribution of 30:70 between DDCs and entrepreneursis rightlyjustified assessing them against the degree of risk involved. The local bodies (with 30\% share) are risk free as shares shall be given only after the plant is operated; whereas for entrepreneurs, $70 \%$ share is justified as $100 \%$ equity needs to be injected at the project outset, making them more riskier.

In such projects the economic benefits (appropriate percentages to be worked through) can be shared through cooperatives among:

a. Daily labourers and lowwage workers (for them, softloans to be provided at subsidised interest rate).

b. Engineers and management cadre people.

c. Every household of the villages.

d. DDCs, VDCs, Municipalities, Chambers of Commerce.

\section{Returns on investment}

Normally a small hydropower project would yield a return on investment (RoI) of $16 \%$. After a fewyears of loan repayment, the cash at the hand of the project would substantially increase. A five MW power plant can produce about 30 GWh of energy, which at Rs 4.40 per unit can produce 130 million rupees annually. In the first few years, most of this would be used to service loans. Once the loans are fully repaid, a significant amount of money remains with the DDC to plan and implement its development and social programs, remaining independent of grants from the central government. Part of this amount could be reinvested in similar but bigger projects to earn more development funds in the future and to have multiple chain impacts.

Available projects

There are more than 6,000 rivers and rivulets in the country with varying potential for hydropower development. The Department of Electricity Development (DoED) of the Ministry of Energy has been carrying out studies of numerous projects that it intends to award to developers through competitive bidding. These projects could be awarded to the districts concerned.

\section{Conclusion}

Investmentin hydropoweratthedistrictlevel hasmultipleprimary and secondary impacts. This model of development would foster the growth of hydropower projects in Nepal. Its contribution to the energy sector would be about 300-350 MW. Although this is a small part of the country's energy needs it is about half of what Nepal has right now. But there are other benefits as well of this scheme as follows:

1. Mobilization of local resources.

2. Empowerment of villages, DDCs and VDCs; will help produce local entrepreneurs.

3. Development of technical manpower to design, build and operate power plants.

4. Development of infrastructure in the villages.

5. Districts can have their own plan of local electrification from the enengy generated.

6. Industrialization of remote areas that are electrified.

7. Excess energy supplied to the urban areas, contributing to curtailingload shedding problem.

8. Low loss, transmission and distribution cost due to nearness factor.

9. Reduced burden on central government for providing resources to Districts on an annual basis.

10. Fewer brain drains in the villages due to conducive environment creation brought about by infrastructure and market development and electrification.

11. Opportunity forinvestors to inject equity in bigprojects, which otherwise wouldn't have been possible.

12. Meaningful experiences and lessons for enhanced planning of bigger sized projects in the future.

13. An opportunity to test and prove PPP model for national development.

14. Technical Sustainability.

Gyanendra Lal Pradhan, hydropower specialist and entrepreneur, is an Electrical Engineer by training. He is currently Patron and Chief Strategist at Hydro Solutions, Director of Butwal Power Company, Chairperson for Nepal Hydro and Electric Limited (NHE) and Khudi Hydropower Ltd.. He is also the Executive member of Independent Power Producers' Association of Nepal (IPPAN), India Chamber of Commerce and Industry (NICCI), Nepal German Chamber of Commerce and Industry (NGCCI), and Nepal China Chamber of Commerce and Industry (NCCCI). Mr. Pradhan has received the prestigious Best Entrepreneur Award, won the Manager of the year 2006 award, and has been conferred with other recognition for his contributions to the field of hydropower and clean energy.

Corresponding address: info@hydro-solutions.org gyanendra@hydro-solutions.org; 